chapter

$$
\underline{E A R L Y D A Y S}
$$


T he story begins against the background of Temasek and pre-colonial occupation to the residue of British colonial development and the birth of the Republic of Singapore in 1965 as a fledgling island nation state in South-east Asia. With early colonial settlement dating from 1819 with the arrival of Stamford Raffles and the East India Company, the primeval forested and vegetated circumstances of Singapore were transformed substantially to make way for plantation and other forms of agricultural production. Well served by its location as a choke point between the South China Sea and the Indian Ocean, the colony thrived largely on entrepôt trade with the Malay hinterland through concentration of lightering, warehousing and convenient association of locals and foreigners, primarily around the Singapore River. Loosely conforming to a plan, originally drawn up by Lieutenant Jackson in 1822, a 7 to 12 kilometer necklace-like arrangement of settlements was stretched along the southern coast and played host to Malays, Chinese, Westerners, Indians, Burgis and others. Gradually moving into the interior of the island, much of the urban development was ad hoc and often very dense, with rudimentary public infrastructure and other public improvements evolving slowly over time. As in other parts of Malaya under British domination, responses to the dictates of agricultural production, climatic and topographic circumstances involved clear cutting, re-planting, crude channelization, and until later, little treatment of the residuals of production or occupation. As time and continued development wore on, not to mention the economic boon of tin and rubber transshipment from around 1900, Singapore became increasingly dependent upon other parts of Malaya for infrastructural support and, particularly, fresh water supply and with water supply agreements dating from 1927 and extending well up into the early 1960s. The economically extractive orientation of colonial rule, though continuing to emphasize Singapore's relatively advantageous trading position, did little for large segments of both indigenous and immigrant populations. Nearing the time of the birth of the Republic, overcrowded and povertystricken settlements were common, along with frequent local flooding and inadequate utilities. Environmental quality, certainly by modern standards, was almost universally poor leaving most of the island's inhabitants festering in dirty, and dismal conditions. Indeed, Singapore's first Master Plan was approved in 1958. However the conservative planning provisions in the Master Plan were insufficient for Singapore's development needs. Seeking technical assistance from the United Nations, Singapore built up a more comprehensive urban planning system over the years. In tandem, Singapore also created institutions such as the HDB and URA, and put in place pieces of legislation such as the Land Acquisition Act of 1966, both of which proved to be sound and effective. By 1971, Singapore commissioned the first Concept Plan, a long term strategic plan which was influenced by the "Ring City Concept" proposed earlier by the UN experts, and which would guide Singapore's urban development over the next decades. 


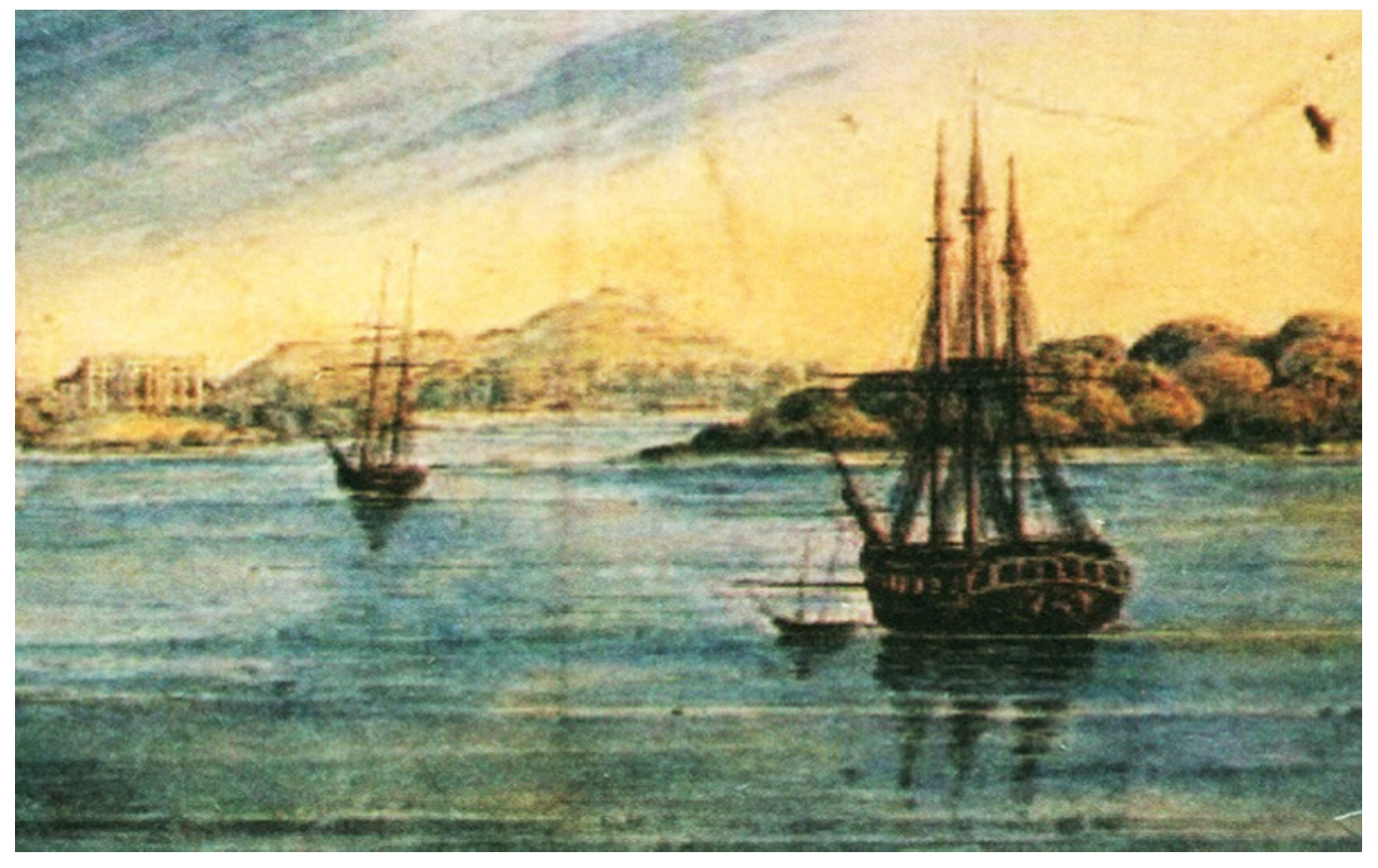

5. OUTCROPS AT KEPPEL HARBOR 


\section{GEOGRAPHIC SETTING AND CONTROL}

One of the earliest accounts of what is now

Singapore dates back to one Wang Ta-yuan's firsthand description, when he traveled in Nanyang, or the South China Sea, in the first half of the 14th century. According to Wang, Temasek Singapore's earliest appellation - was inhabited by some Chinese but also by pirates. ${ }^{1} \mathrm{He}$ also referred to a trading settlement near Long Ya-men - Dragons Teeth Gate - probably making reference to outcrops at the entrance to Keppel Harbor. A navigator during the early Ming Dynasty, Wang also observed how westbound ships crossing the Sunda Straits in front of Temasek were left untouched, while those moving eastward into the South China Sea were often attacked by numerous and armed boats. Earlier written accounts still came by way of P'u Luo Chung and his rendering of the Malay Pulau Ujong, or island at the end of the Malay Peninsula as far back as the third century A.D. ${ }^{2}$ Inhabitants were reported to be primitive cannibals also preying on junks plying their way back and on through the South China Sea. Temasek was a choke point in the former Sunda Shelf that once linked the Malay Peninsula to the islands of modern Indonesia. ${ }^{3}$ This location was such that refuge could be sought between the seasonal north-east and south-west monsoonal winds, also facilitating navigation both in and out of the South China Sea from the Indian Ocean to the south and west. Indeed, Temasek and now Singapore enjoyed the advantage of command of sea lanes valuable to trading, good anchorage, and sufficient local resources in the presence of potable water, along with defensible positions. These attributes persisted well into the modern era, becoming a leitmotif of Singapore's comparative advantage.
Later on Temasek found itself in the throes of the power struggle between the Srivijayan Empire to the west and the Javanees Empire of the Majapahit to the east. At one time the Srivijayans occupied significant areas of the Malay Peninsula and nearby islands, with Palembang at its heart on today's Sumatra. Apparently, during an inspection tour of the islands Prince San Nila Utama came upon the shores of Temasek near the estuary of the present Singapore River, also observing what seems to have been a lion. ${ }^{4}$ According to the Malay Annals he then founded a city at Kuala Temasek which he called Singapora, or the 'Lion City'. ${ }^{5}$ Later, in 1365, Temasek was claimed by the Majapahit and made a vassal state. Retaken by the Srivijayan forces in 1390, Iskander, its leader was driven out of Palembang, its capital, and sought refuge in Temasek. As a city, Temasek faced out to the sea and was walled on its northern side by an embankment of compacted earth about five meters wide and three meters in height, stretching from the sea about 1.5 kilometers around the edge of what became Fort Canning Hill. ${ }^{6}$ The Singapore River made up most of the southern side of this defensible redoubt. Internally, it was probably comprised of a kampong with timber and thatched buildings, elevated above the ground for ventilation. Inhabitants of Temasek may have engaged in an early form of entrepôt trade, although corroboration by early visitors like Wang Ta-yuan and the Portuguese Torre Pines was not forthcoming. As the historian C.M. Turnbull concludes: "Temasek was a small outpost of Srivijaya, its people harnessed to the sea power of the Empire or, in more troubled times, exploiting their position to prey on other's trade" ${ }^{7}$ In the meantime, Temasek was renamed Singapura, or the Lion City. 


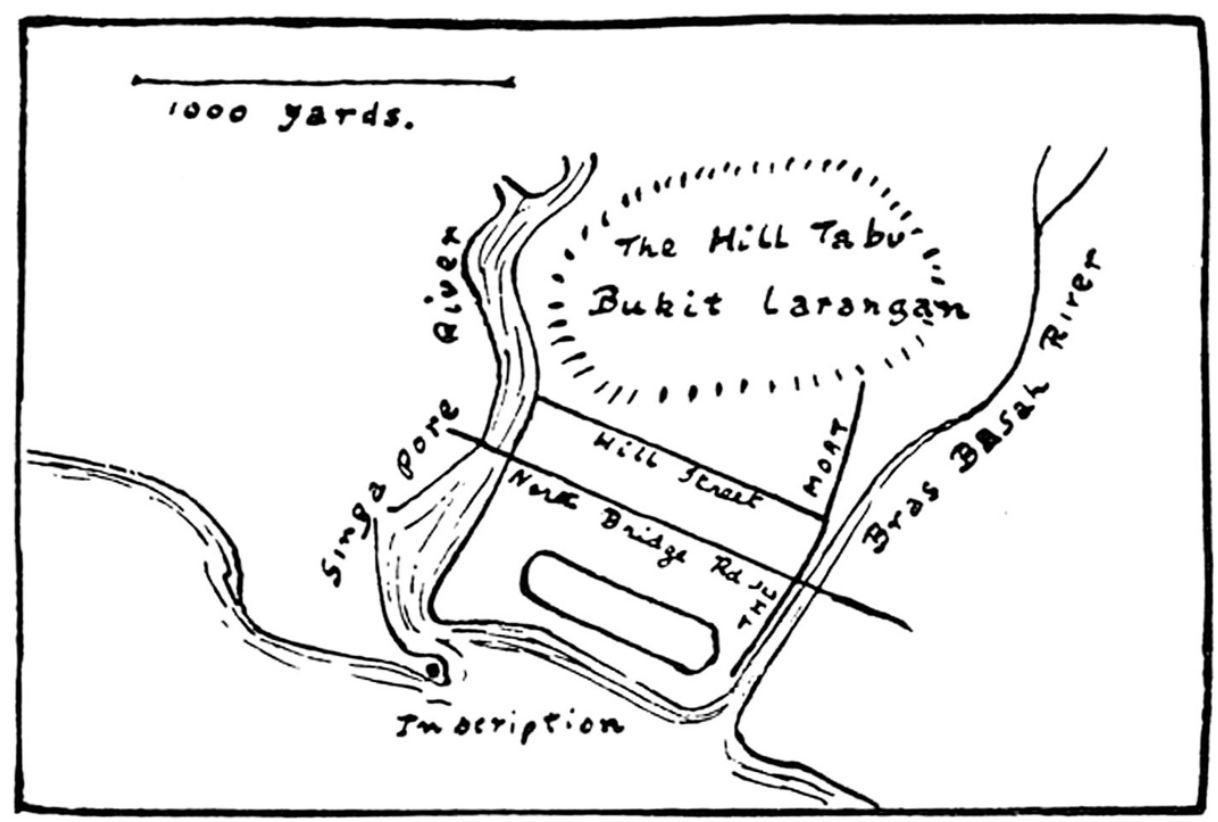

6. PLAN OF TEMASEK

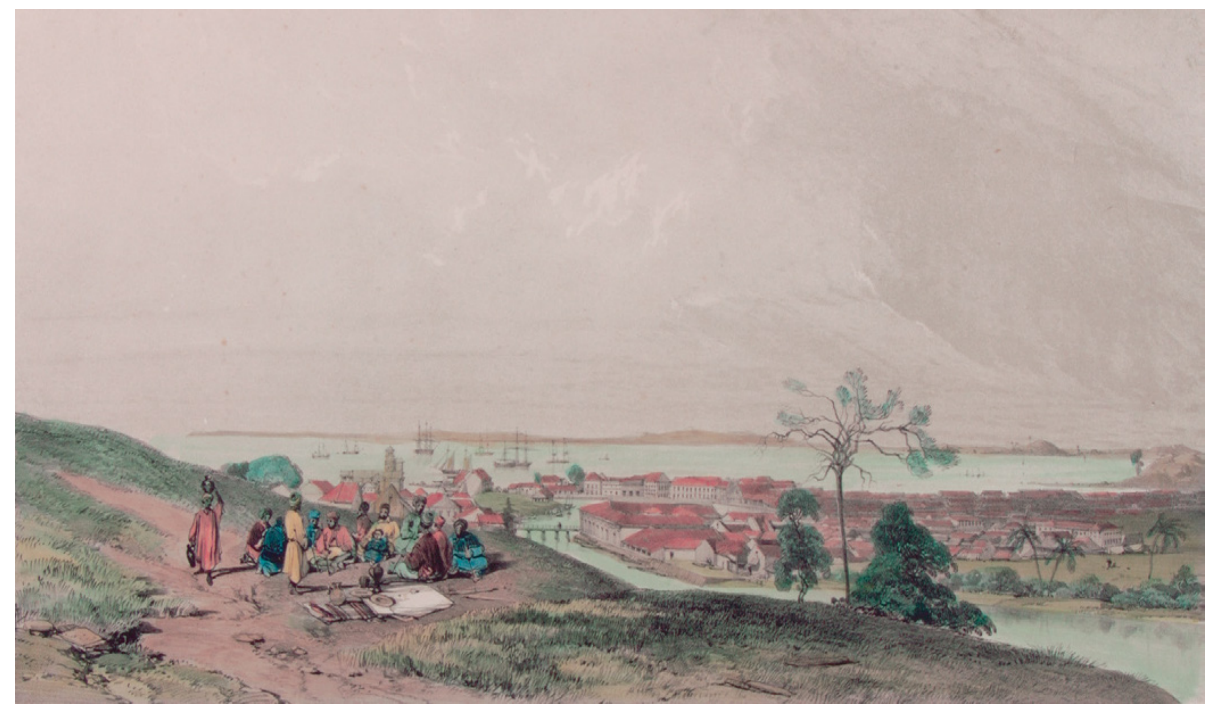

7. HARBOUR AND TOWN OF SINGAPORE 
Although not completely deserted after Iskander's flight around 1398, Singapora and the areas around it remained relatively abandoned. It was occupied largely by orang laut or sea nomads who led an existence sometimes trading with passing ships or lying in wait to plunder them. ${ }^{8} \mathrm{~W}$ ith the fall of Malacca in 1511 to the Portuguese, Singapora became an outpost of the remnant Malaccan Sultanate. This was a position that Singapora held, in spite of the Portugese destruction of the Sultan's naval power in 1507 , and successful attacks on Johor. In time the Sultanate retreated in part to Singapora becoming the Temenggong Rulers. For the next 150 to 200 years beyond the sixteenth century, however, the importance of the island dwindled appreciably. This was due to the loss of Malay power in the region leading also to a power vacuum and isolation. The area lost out to Malacca with regard to trade and commerce. In the first decade in the nineteenth century Temenggong's Abdu'r Rahman set up a village on the former site of Singapora, associating himself with a small band of Malays gathered from the orang laut tribes. In total there were perhaps 1000 inhabitants mainly orang laut and small numbers of Chinese, as well as some 20 to 30 Malays in the Temenggong's entourage. At the time this was a typical Malay-ruled village, consisting of the Temenggong's substantial timber house, surrounded by thatched atap houses. Inhabitants grew fruit and depended largely on their livelihood by collecting jungle produce, fishing, small-scale trading and piracy. The most noticeable aspect of the last pursuit was the Golang pirate fleet of 1818 with some 50 ships and about 1,200 men. In addition, there were a number of Chinese engaged in agricultural development in the interior, particularly in 20 to 30 gambier plantations, producing an extract and popular betel nut, with pepper as a supplemental crop. The island was far from pristine in indigenous plantation and wildlife.

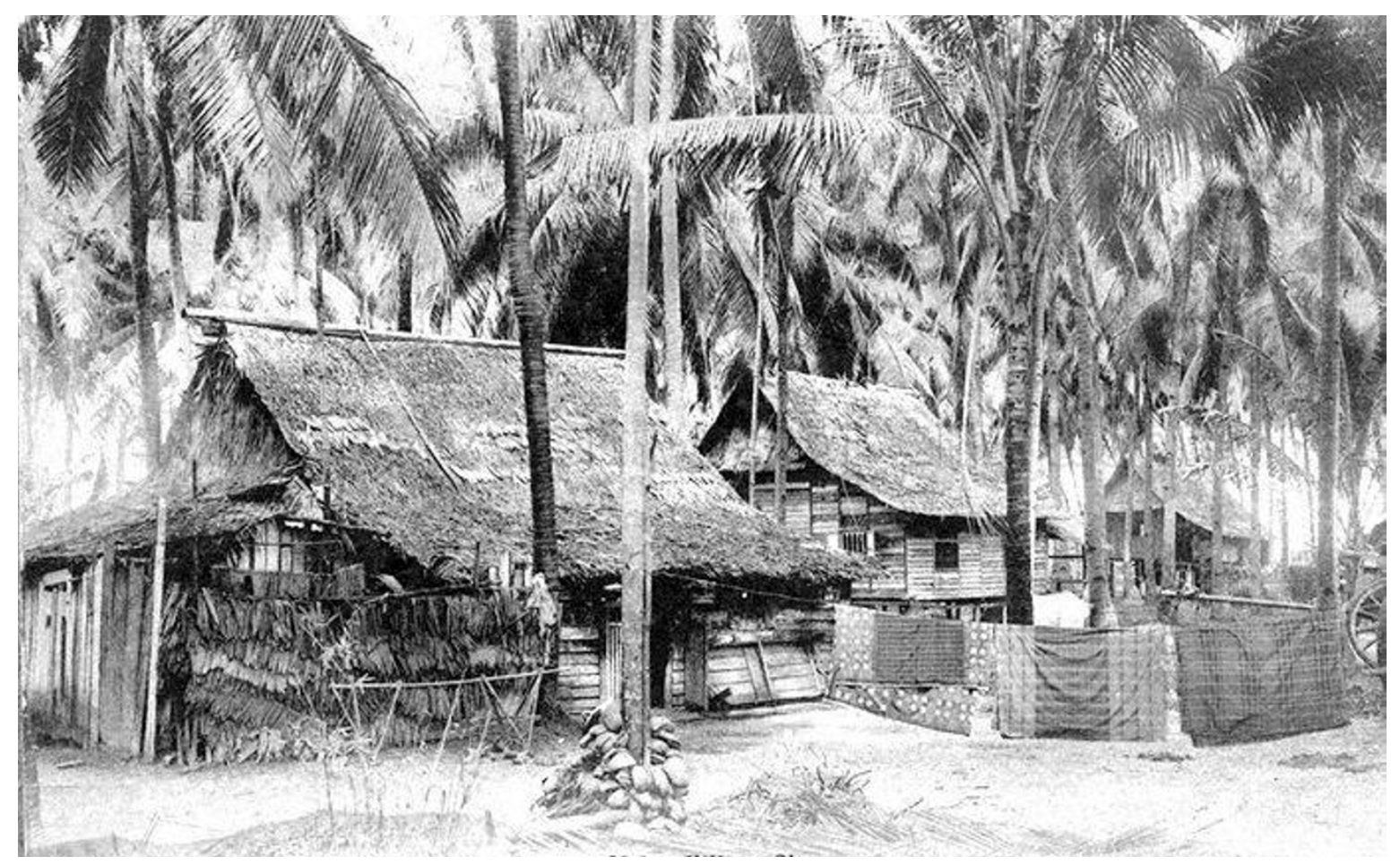

8. A MALAYAN STYLE KAMPONG 
Less locally, the early nineteenth century world was one of mercantile capitalism with European imperial powers actively engaged in controlling important sea lanes to further their trading interactions especially with East Asia. At first this engaged the Portuguese, trading from Macau through the South China Sea to Malacca and then on to Lisbon via Goa, Mozambique and Angola. Then there were the Dutch in the seventeenth century establishing a headquarters in Batavia on Java and bypassing the Portuguese in Malacca through the Sunda Straits and into the Southern Indian Ocean and before interdicting themselves into Ceylon in 1640 and Malacca in 1641. This enabled them to both dominate the Sunda and Malacca Straits for roughly 150 years. To counter these Dutch ambitions, the British attempted to secure a foothold at the southern end of the Straits of Malacca, proximate to the Sunda Straits and effectively securing sea routes to China and the Malay Archipelago for British trade. In 1819 an expedition led by Stamford Raffles signed a preliminary agreement with Temenggong Abdu'r Rahman the local ruler of Singapora. This was later ratified in the same year in the manner of the doctrine of 'indirect rule' authorizing the British East Indian Company to establish a factory or trading facility in exchange for British protection and 3000 Spanish dollars annually. ${ }^{9}$ In effect a lease-hold or 'use right' agreement was consummated. Raffles was an uncommon if controversial administrator. At the time he was the Lieutenant-Governor of Bencoolen, a British possession in Sumatra since 1685, when he abolished slavery among other reforms. He was also an agent of the British East Indian Company with the profit-making orientation that went with the position. More personally, Raffles was an ardent student of local customs and languages and largely possessive of an enlightenment mind-set. However, it wasn't until 1824 with the Anglo-Dutch Treaty in place and with the Residency of John Crawfurd that the British consigned sovereignty to the entire island. Further in 1826, the East India Company united
Singapore with Penang, Malacca and several other states to form the Straits Settlements with Singapore as the capital under a Governor. At the time of the first census in 1824 the island's population was counted as 10,683 people.

The 'Town of Singapore' as it was called was represented cartographically by Lieutenant Philip Jackson, at Raffles request, in 1824. Earlier on in 1819 Colonel William Farqhuar, a friend of Raffles and long-serving officer in Malacca and the Riau Archipelago, set about clearing land on the northeast bank of the Singapore River for a market and cantonment of temporary huts. ${ }^{10}$ Jackson's plan, overall, was a necklace of communities largely consolidating who and what was in place. Roughly from west to east, there was the Malay Kampong, next to the Chinese settlement on the western side

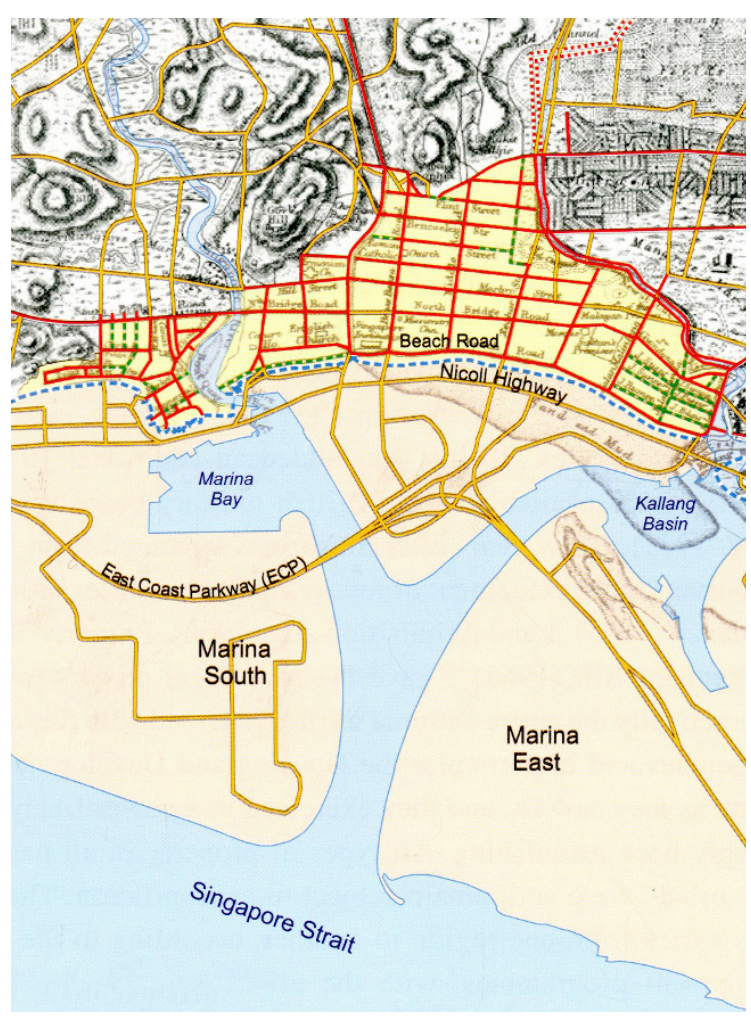
9. LT. JACKSON'S PLAN OF SINGAPORE
IN CONTEXT 
of the Singapore River. Across from that was the Government Centre and European Town, trailing off into the Arab and Burgis areas. In area the plan inscribed a coastal zone of 6 or 7 kilometers in length and around 1.5 kilometers in width. Although not entirely according to Raffles wishes, the ethnic separation was how matters were at the time and not untypical of British colonial settlements elsewhere. Major influences in the plan were largely Palladian and Neoclassical, reminiscent of Nash London in 1812.

Organizationally, rectangular grids of streets and roads of various dimensions were deployed along the coast, also with a sizable public space or Padang. ${ }^{11}$ Topography also played a role, with Fort Canning Hill dominating the European community, crowned by Government House. British power and wealth was projected through the image of Palladianstyle buildings lining the major roads in the plan, especially in comparison to smaller allotments given over in the plan to Chinese shophouses to the southwest. The Singapore River served as the major port of commerce and mercantile activity, involving lightering from and to larger ships at anchor in nearby Keppel Harbor. In short, during the early colonial period, Singapore was a relatively small but growing settlement, increasingly under British hegemony, consisting in form of relatively separated enclaves, although becoming mixed in some cases along the coast. The settlement also had a distinct urban and administrative centre and port facilities, adjoined by looser collections of largely detached dwellings and shophouses.

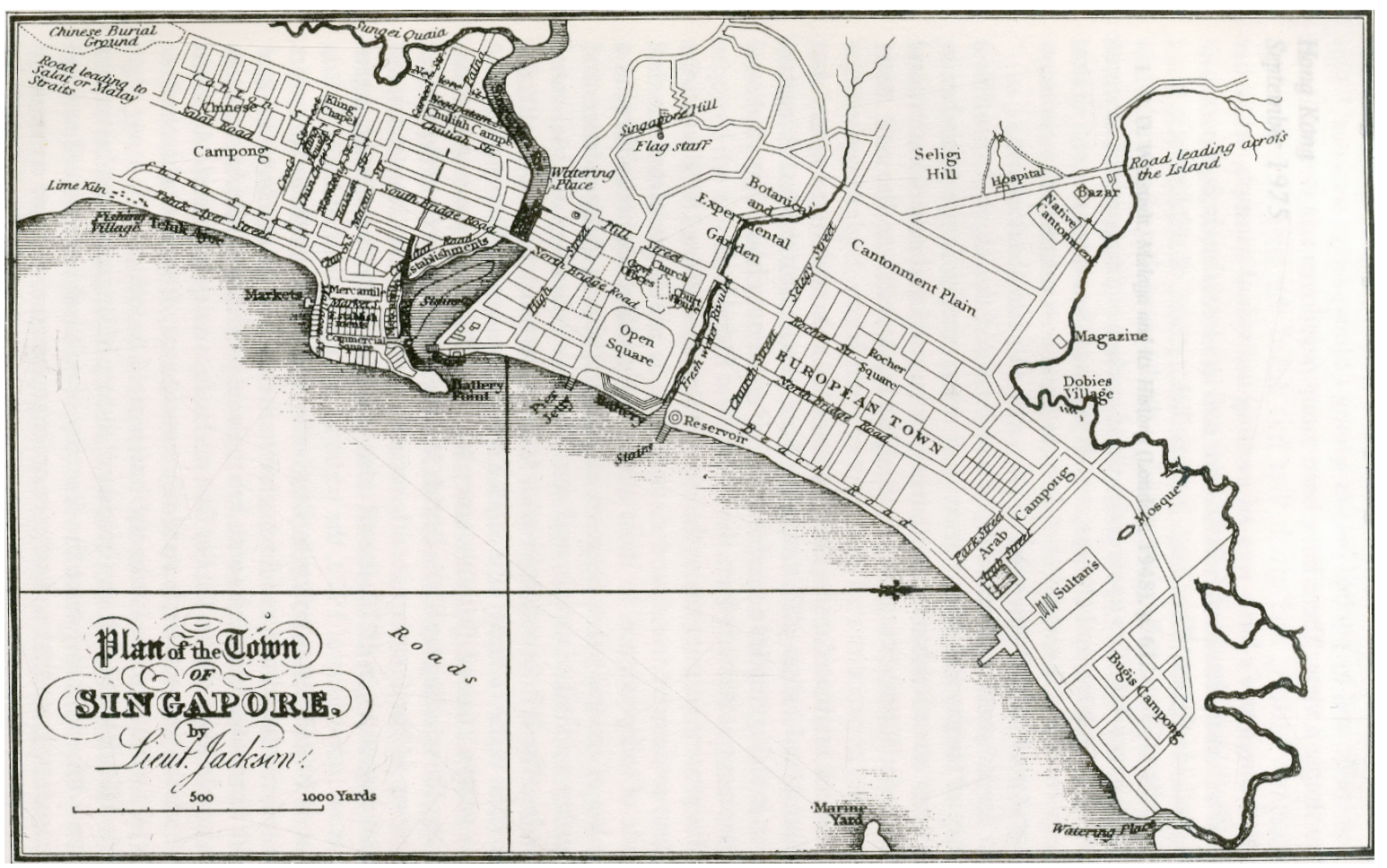

10. A PARTIAL SCHEMATIC OF LT. JACKSON'S PLAN FOR SINGAPORE 


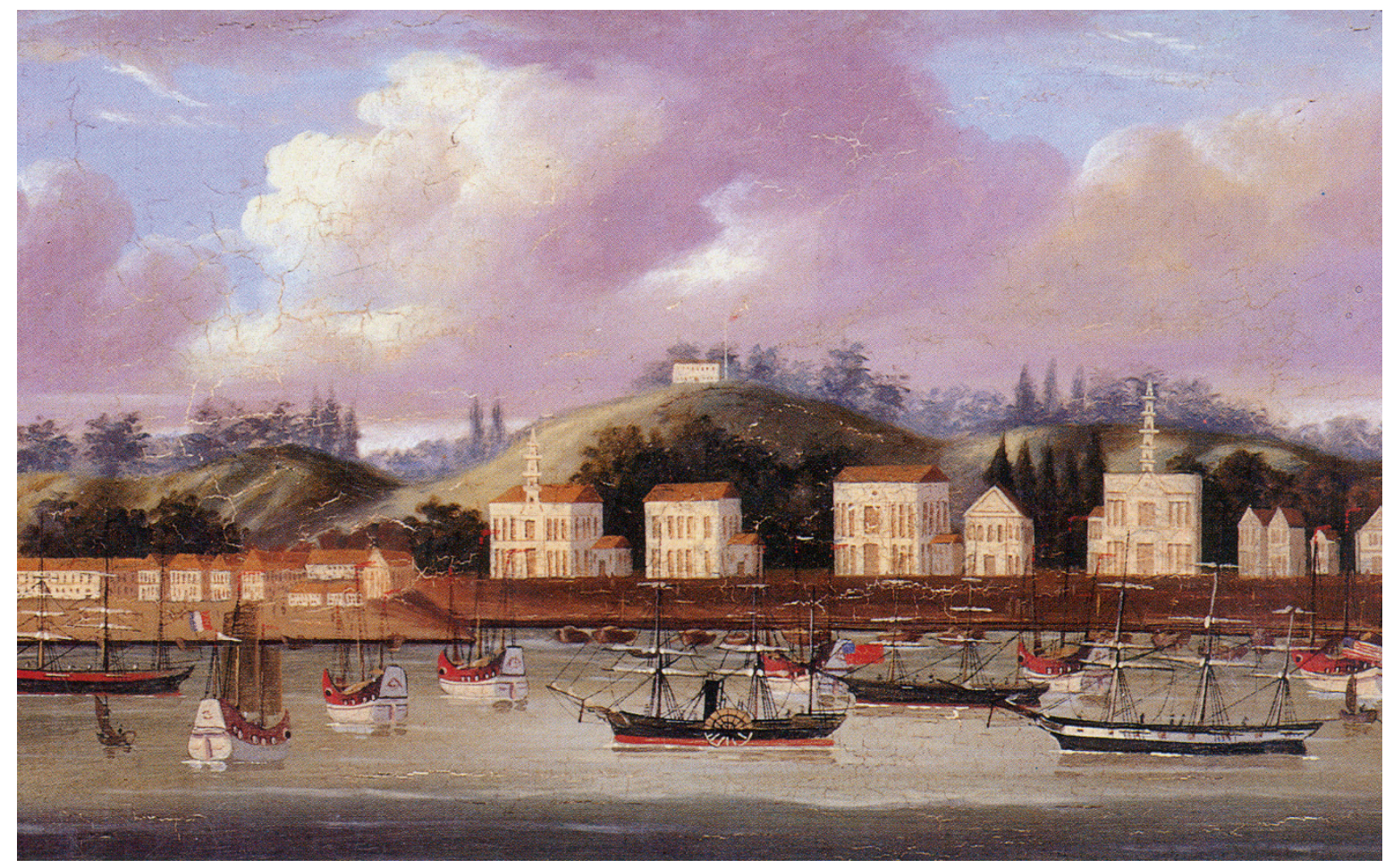

11. DEPICTION OF FORT CANNING AND ENVIRONS

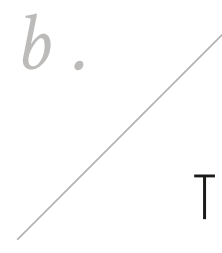

\section{TRANSFORMATION}

As mentioned earlier, at the time of Raffles arrival the island of Singapore was not totally pristine. orang laut settlers were located north of the Singapore River, at the mouth of the Kallang River and in the estuaries of the Punggol and Seletar Rivers, as fishing communities mainly, with marginal impacts on the land. ${ }^{12}$ At the time the three significant ecological habitats were the primeval forests, the freshwater swamp forests and the mangrove forests. However, by the middle of the nineteenth century the spread of gambier and pepper plantations along with other crops led to the almost total deforestation of the island, with the exception of a few hilltops and steep slopes. Lalang grass and brushcover took over in the absence of crops and other forms of ground cover. Gambier, pepper and nutmeg introduction led to numerous plantations on the interior serving global markets. Then spices were replaced in the earlier twentieth century by rubber plantations up until the Japanese occupation. Also farms to feed 


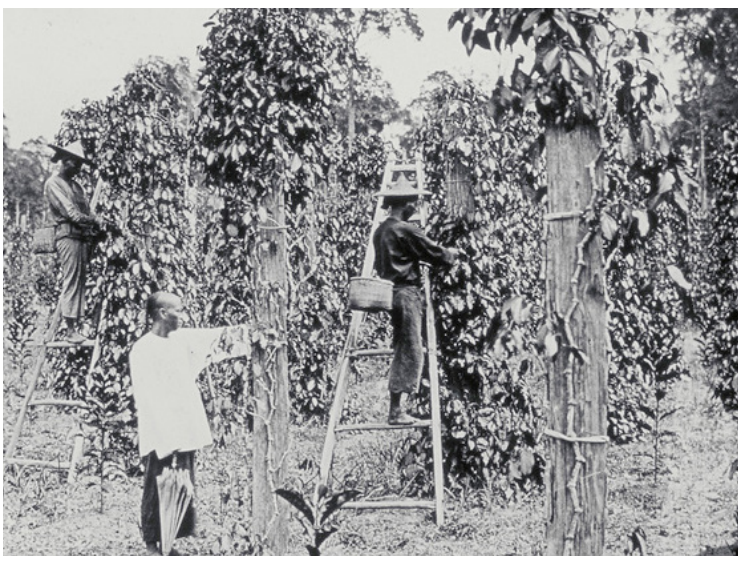

12. A GAMBIER-PEPPER PLANTATION

the population developed even making Singapore self-sufficient in pork, eggs and poultry into the 1980s. ${ }^{13}$ Very early on even Raffles decided that potentially valuable land should not be wasted in the construction of a township. After all, spices were the corner stone of most European trade in South East Asia and also behind much of the Anglo-Dutch naval tussle. Also as a part of the British East India Company efforts to gain a foothold in Singapore Raffles established experimental botanic gardens next to his residence at Fort Canning in 1819, leading to many nutmeg plantations until they were wiped out by parasites in the 1850 s and 60 s.

Early Chaozhou immigrants from Guangdong Province in China also brought agricultural practices and the Kangchu system of social organization to Singapore in the late 1700s. This system revolved around the Kanglar or riverine village headquarters comprised of administrative buildings, general stores, opium dens, and gambling houses, from which radiated out pigsties, vegetable farms and orchards. These Kanglar resulted in a number of bangsals of cleared land for gambier and pepper production. ${ }^{14}$ In total, nine to ten men worked a bangsal which became depleted after some fifteen to twenty years, leading to outward expansion of the settlement to create new bangsals. The abandoned areas either reverted to secondary forest or, more likely, to useless lalang grass areas. Rivers and streams were the main avenues for movement into the interior, as roads to Bukit Timah, Kranji and Sarangoon were only established several decades after 1819. In essence, reliance on river transportation meant that kanglars were close to navigable water ways. In short, the development of remote areas of Singapore began along rivers and expanded outwards from central villages. The interstitial locations within this kind of network also provided the broad palm leaves used for roofing, among other purposes.

Both gambier and pepper cultivation and production were destructive in other ways, apart from consuming land area and depleting soils where they stood. Both crops required large amounts of timber for processing through the boiling of leaves and kiln drying requiring extensive amounts of fire wood. This, in turn, led to logging and deforestation. In fact, a report in 1883 showed that a typical bangsal, of the kind described earlier, consumed 2,500 pounds of timber per day, or roughly the same equivalent area of forest as was consumed by the planting of crops in the first place ${ }^{15}$. Certainly by the end of the 1940s and mid-century, the destructive face of gambier and pepper planting were beginning to become clear to Singapore's residents. Another sideeffect was the adverse impact on wildlife and birdlife, including virtual extinction of native and rare species like the Oriental Pied Hornbills. Malaysian tigers among larger animals adapted to radically changed vegetated circumstances by beginning to prey on domestic livestock, dogs and even humans. The last tiger was shot apparently in 1930 having been considered legitimate threats from around the 1830s onwards. Today there are no Malaysian tigers in Singapore due to hunting and diminution of habitat. Eventual decline of gambier plantations was due to the lack of timber resources for processing and land title regulations put into effect in the late 1850s to regulate production and falling prices of crops. The upshot also, however, was that the land was exhausted and almost completely deforested by 1900 . 


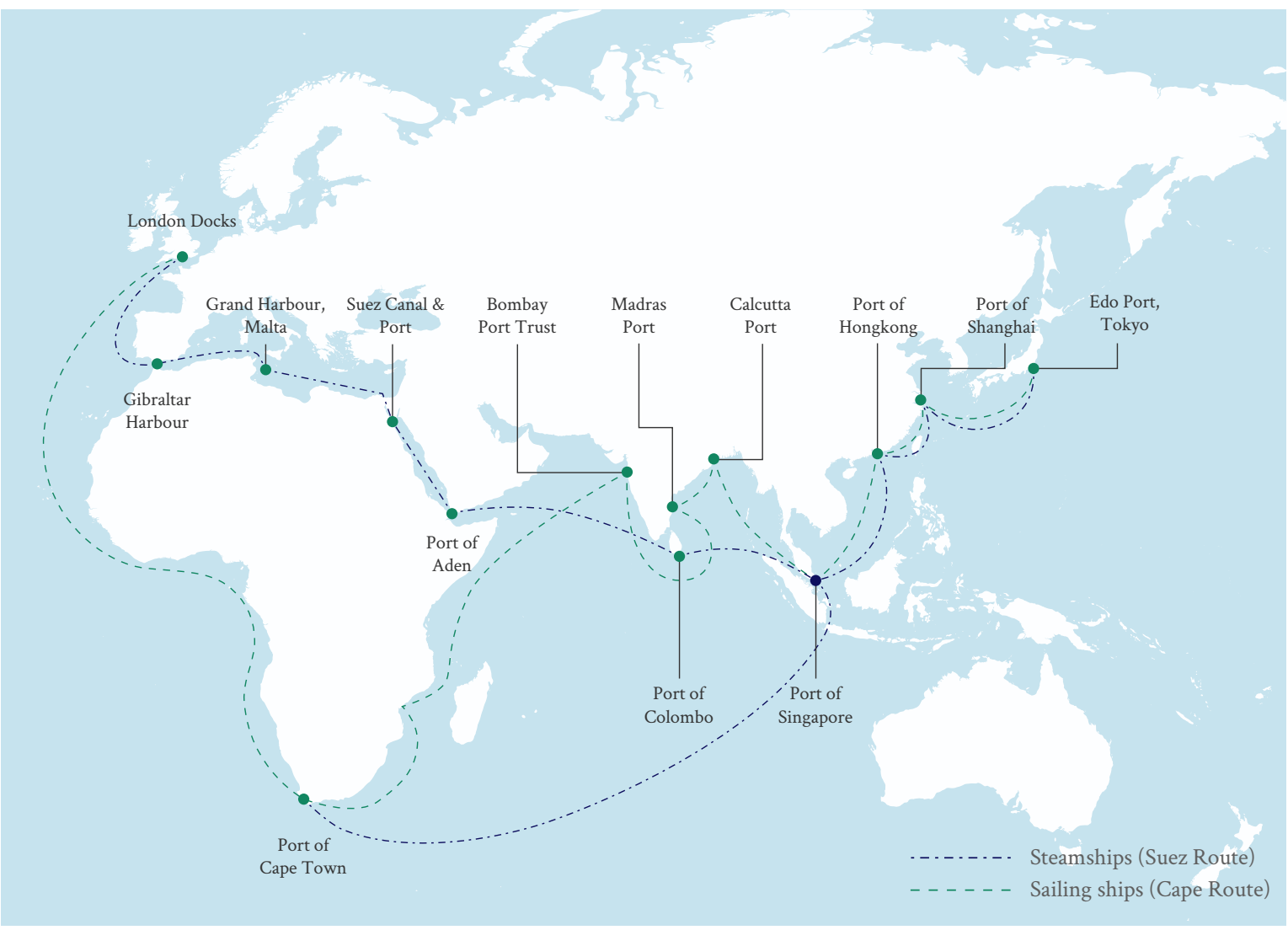

\section{MAP OF SEA ROUTES TO SINGAPORE.}

The second half of the nineteenth century, saw many plantations moved off-shore to Johor but the Kangchu system of settlement continued with rivers remaining the principal channel of communication. ${ }^{16}$ By the 1840s the Europeans had ventured to Bukit Timah, the highest point on the Island and encountered the deforestation of Chinse agricultural practices. By the late 1870s the government of the Straits Settlements decided to look into the state of natural forests with the issuance of McNair report in 1879 and something of a wake-up call for government. Following that, Nathanial Cantley was commissioned to prepare a report on the Crown Forests of the colony which came out in 1883 as a scathing report on government efforts to conserve forested land. With the establishment of a Forestry Department in 1884, steps began to be made to implement recommendations to conserve forests Generally they were divided into three categories: town reserves, coastal reserves, and interior reserves, totaling some 1,260 hectare; 920 hectare and 2,400 hectares respectively in area. This represented only 8 percent of the total area of around 540,000 hectares of land at the time. In other words, after some 50 years of gambier and other forms of cultivation over 90 percent of the forested areas of Singapore had disappeared.

By the last quarter of the nineteenth century, prosperity began to accrue to Singapore, although not in agricultural production. In 1875, for instance, Singapore had become South East Asia's major entrepôt with trade increasing something like eight times in five years. Again strategic location 
played a role with the Suez Canal opening in 1860 and the need for important ports for bunkering in a far reaching chain that stretched from China to Singapore to Bombay, through the Suez Canal onto Europe. ${ }^{17}$ There were, however, four other factors behind Singapore's success apart from location. First was the style of entrepôt trade with private enterprise at its core and a cooperative engagement between government and the private sector, but with no customs controls and cohongs in between. Second, there was the presence of free trade. The monopoly of the British East India Company was broken in 1833 making Singapore very attractive to both Western and Asian traders. Third, there was the presence of a sufficient hinterland, especially post 1874 when the British gained control over the Malay States and the Straits Settlements became a Crown Colony in 1867. Finally, there was Pax Britannica in which British naval power ensured peace and prosperity keeping the sea lanes open. Indeed between 1863 and 1926 there was a 20 times increase in trade, the most substantial in Singapore's history until the past 25 years. Population pressures pushed town development into its suburbs, especially along internal roads such as Orchard Road. Migration occurred within established sections of Singapore with an ethnic remixing phenomenon, where decentralized areas became more mixed except for the further out one went into the country side. At the close of the nineteenth century the population rose to 226,842 inhabitants with 75 percent Chinese, 14 percent Malay and 9 percent Indian. There were relatively few Europeans. Also at the close of the nineteenth century Singapore became one of the world's largest sea ports, ranked around seventh behind Liverpool.

\section{SECURING PROSPERITY}

Around 1900, two events secured the continued prosperity of Singapore. One was the invention of the automobile and the need for rubber products produced mainly in the Malay hinterland. The second was food perseveration and innovation and the canning of goods using tin, also from Malay alluvial sources. Although not that sharply defined, the period from 1900 to the 1930s saw a productive intermixing of three intertwined phenomena.

The first was booming population growth with an almost doubling from 200,000 inhabitants in 1895 to 398,000 inhabitants in 1920 . This was followed by only a somewhat lesser growth between
1920 and 1940 of 398,000 to 755,000 inhabitants or thereabouts. ${ }^{18}$ The second tied to the first was immigration and more important, public expenditure on municipal services and improvements. With the population effectively doubling between 1920 and 1930 most came by way of Chinese immigration to Singapore in probably the highest proportion in Singapore's history, at least up until that point. Many were escaping the turmoil in China at the hands of warlords on the heels of the Republic of China of 1911-12. As elsewhere, there was also a change in the laisse-faire attitudes on the part of the British, now replaced by more of a concern for 
social equity and social progress. In Britain the flagrance of the Victorian period could no longer be supported economically. Industrialization and companion urbanization led to counterproductive squalor and disease. ${ }^{19}$ All of this gave rise to reform movements and concern for social causes, particularly among informed elites. The third phenomenon, again as elsewhere, was the emergence of civil society, albeit along ethnic lines but also reflected in Singapore's urban fabric. The Chinese, for instance, formed their United League in 1900 and 1910; the Malays the Singapore Malay Union in 1926; and the Indians the Singapore Indian Association in $1923 .^{20}$ Each group was preoccupied in different ways with different issues, but local politics became very much the domain of the Straits Chinese and British attitudes were both harsh to nationalists and subversives.
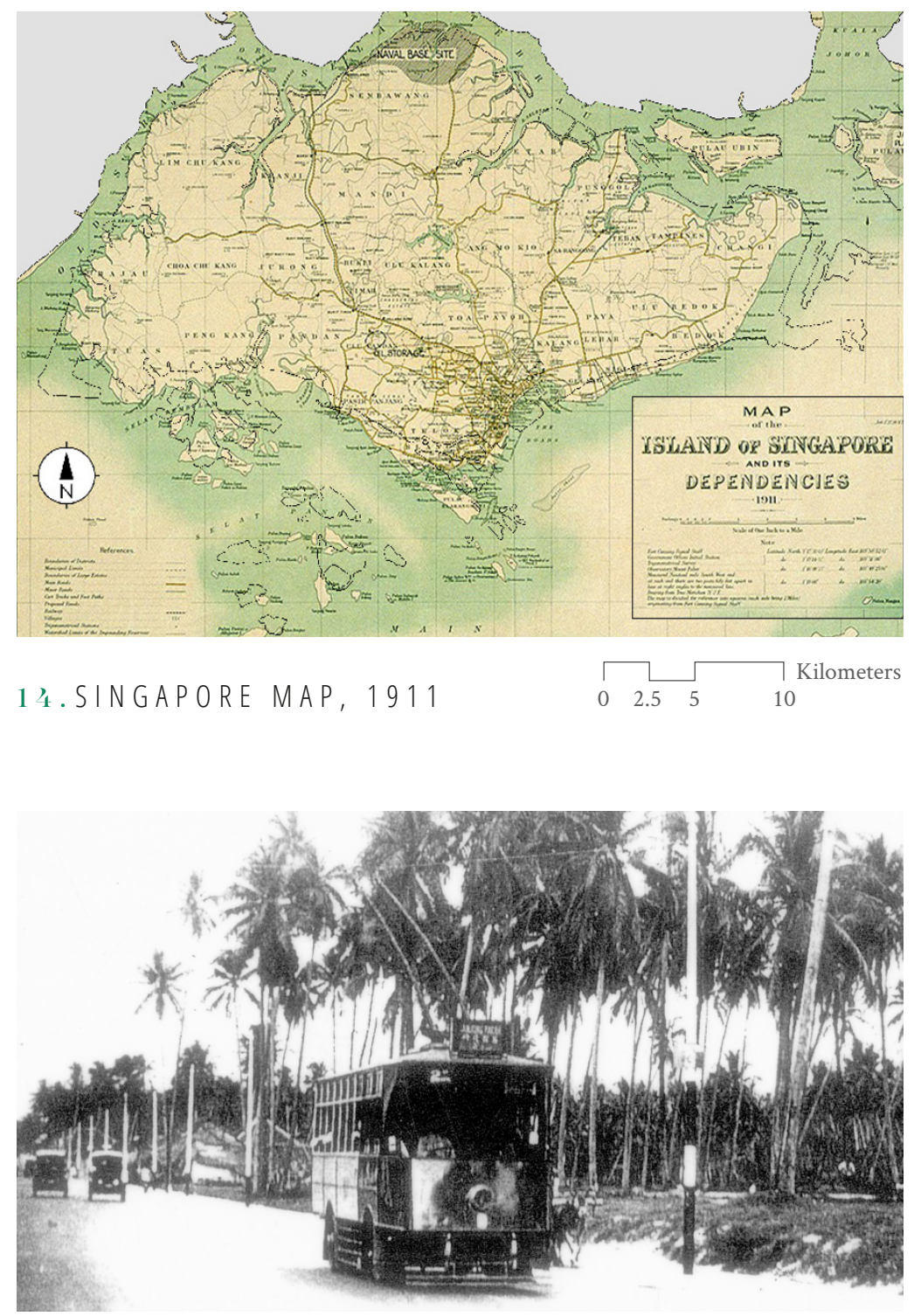

15. A TROLLEY CAR ON GEYLANG ROAD 
One conspicuous upshot of this period was a concern for a widening gap between' haves' and 'have-nots, as well as improved living conditions and public works. Squalor and social divisions were reacted to through regulatory controls and expenditures on public services, public health and public safety. More specifically there was enactment of a 'light and air' regulation in 1896 and the examination of housing conditions published as the Simpson report of 1897, that eventually led to a Housing Commission or Trust to deal with squalid housing and with legislation allowing the tearing down of slums. By 1913 there was a government ordinance regulating sewer and street lighting similar to elsewhere in Britain, the United States and Europe. Certainly by the 1920s public provision of infrastructure and modern elements of planning had arrived in Singapore, including transport, public parks and roads. Again as elsewhere, more affluent suburbs became better served than poorer inner city areas. Reservoir construction that had been more or less continuous since 1867 , mainly due to population growth, with the MacRitchie Reservoir, named for the engineer who designed and built it. ${ }^{21}$ The Kallang Reservoir followed in 1911 and the Sungei Seletar Reservoir followed 1922. Effectively in 1900 the entire catchment of the Kallang and Seletar Rivers above the dam walls became the Municipal Catchment, also protecting secondary and primary forest within that area. This was later gazetted as a Nature Reserve in 1951. In retrospect construction of these reservoirs was seen, by some, as both a blessing and a curse. Of course there was some abundance at the time of clean water and vegetation conservation, but also the loss of fresh water marsh forest.

Returning to rubber production, Singapore though a minor producer, had major impacts on research into para-rubber trees at the botanic gardens. There the work of the botanist Henry Nicolas Ridley was instrumental in promoting rubber trees in the Malay Peninsula and making the industry economically viable. $^{22}$ In Singapore itself there was some production in the form of several large plantations, on the order of 8,000 hectares or so in size. The Great Depression, however, at the end of the 1920s and into the 1930s adversely affected rubber and latex production with prices falling precipitously. Over time, the declining rubber plantations were replaced by intermixed vegetable farms well into the Japanese occupation. In addition to rubber, tapioca and Liberia coffee were experimented with as cash crops, particularly by Leopold Chasseriau on his 485 hectare estate adjacent to the central catchment area. These experiments had, however, no lasting impact.

Between 1819 and 1945 Chinese Singaporean farming was effectively locked into the British system of distribution of economic development. ${ }^{23}$ Small-scale local family farms increased agricultural output to meet demands of rising populations, producing cash crops like gambier, pepper and nutmeg. With withdrawal of the East India Company in 1834, some former employees also farmed plantation agriculture for profit. Chinese businessmen often supplied the system with labor via a 'Credit Ticket System' of labor recruitment. Under this punitive arrangement, Chinese passage was arranged and paid for by working at least a year at reduced wages. In addition, a proportion of the wages was paid for in-kind with food, clothes and opium. The resulting cheap labor was thus exploited for agriculture with the small-family farms excluded from these processes and receiving little government support. Many cheap laborers also lived in the over-crowded areas of Chinatown and other locales, exacerbating the squalor and poor quality of life in the city mentioned earlier. In 1905 a cholera epidemic claimed 759 victims, mostly Chinese. Unlike the plantations that were inflexible with their crops, plagued by poor and exhausted soils and encountering plant disease, the small-scale farms of the Chinese agriculturists proved to be flexible, low in overhead and highly productive of food. Indeed, in 1945 family farms were the most important agricultural activities on island, despite also producing pollution problems. 
To briefly summarize the state of affairs before World War II, the early colonial administration of Singapore engaged in little land management. Population expanded appreciably. There was a minor boom in rubber latex production using Ridley's herring-bone method of extraction. Catchment areas were developed along the reservoirs. However, the original dryland primary forest shrank from 410 square kilometers to 2.01 square kilometers; the fresh water swamp forest declined from 74 hectares to a mere 1.33 and the mangrove forest from 87 ha to 5.7 square kilometers. Overall the original primeval forest of 571 square kilometers diminished down to 9.04 square kilometers, or a mere 1.58 percent of its original scale. Mostly this was due to unproductive agricultural production and misguided land management. ${ }^{24}$
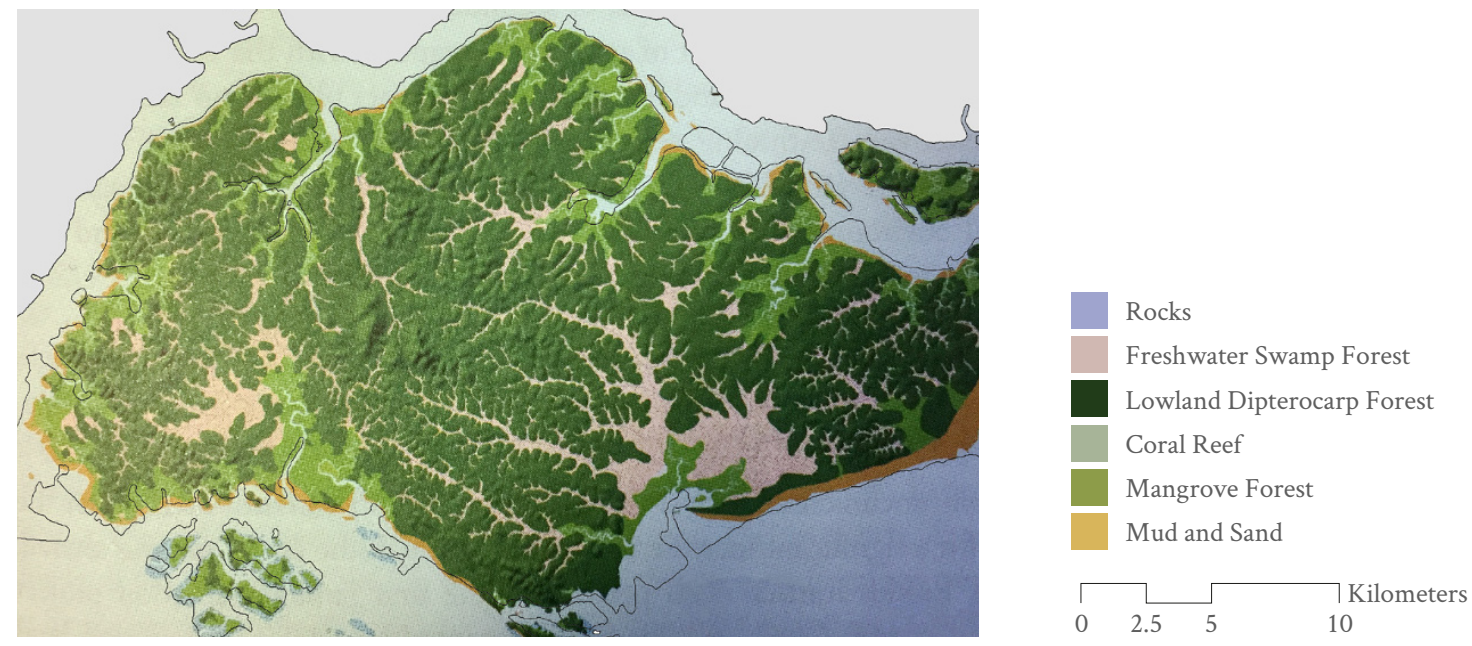

16.MAP OF SINGAPORE'S PRIMEVAL FORESTS

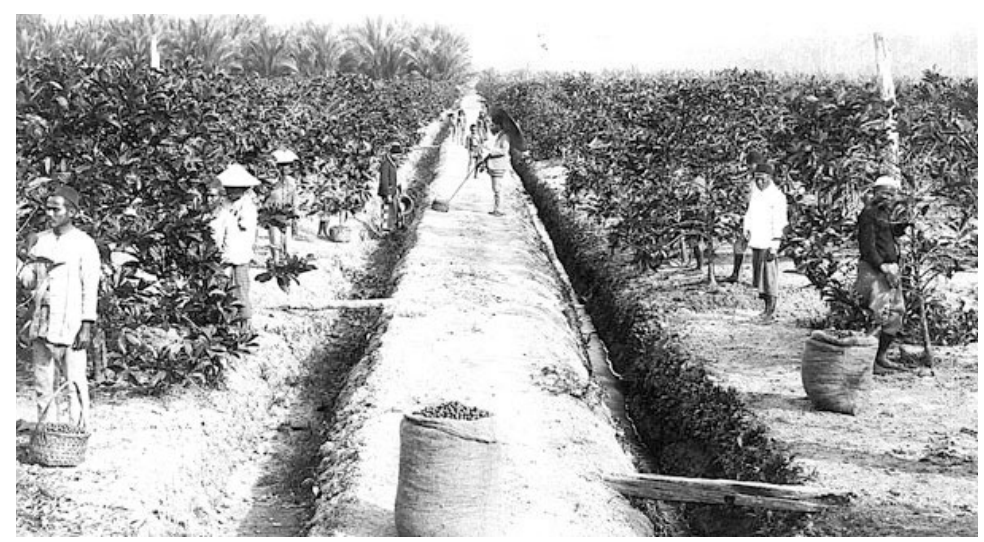

\section{A DEFORESTED PLANTATION IN 19TH CENTURY SINGAPORE}




\section{WAR-TIME INTERLUDE}

At the time of Japan's military campaign to create its Greater East Asia Co-Prosperity Sphere defenses at Singapore, both at Changi and Jurong, were oriented towards seaward attack. Instead, Lieutenant-General Tomoyuki Yamashita's army swept down the Malay Peninsula crossing easily into Singapore Island.

After valiant resistance by Commonwealth and local forces, Singapore fell to the Japanese in February of 1942, also opening the way to conquest of the Netherlands' East Indies. The Syonan years ('light of the South'), as the Japanese occupation has been called, was a period of considerable confusion for the people and defenders of Singapore. ${ }^{25}$ For more than a century the security of Singapore in British hands was taken for granted. Under the Japanese the

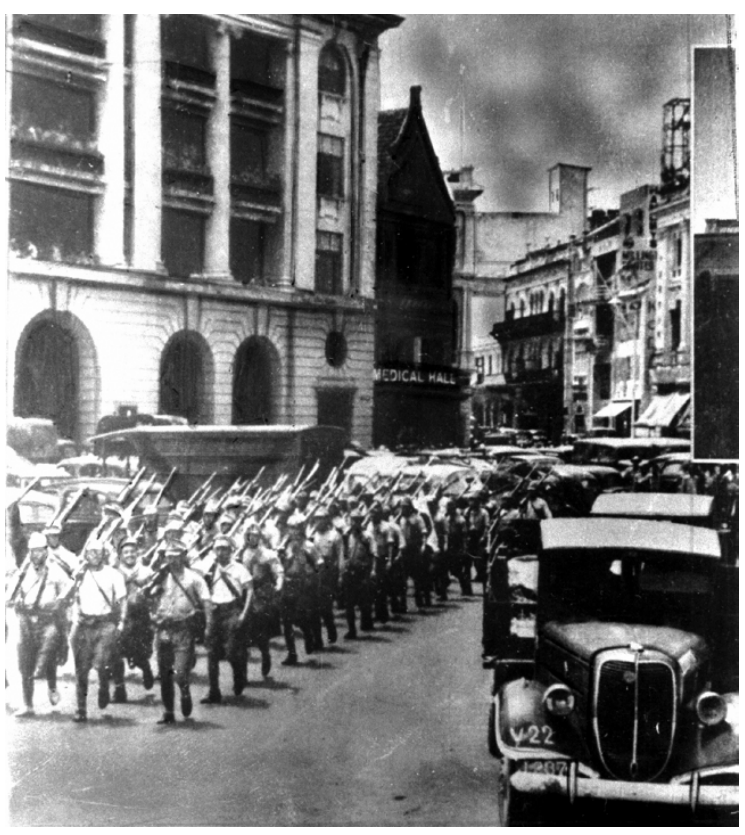

\footnotetext{
18.JAPANESE OCCUPATION OF SINGAPORE.
}

city with a population on the order 800,000 was ran by a municipal administration or tokubetsui-si but under the military administration or gunseikan-bu with the Kemppeitai, or military police, holding sway. What took place was a 'reign of terror' during the first months of occupation, if not longer, involving purges, torture and massacres. Generally the Chinese population was brutally treated, partly because of gallant and persistent Chinese resistance to the Japanese attackers. The Malays were left somewhat more alone and the Indians were invited to join forces with Japan, which some did. All the Westerners were interned in concentration camps. ${ }^{26}$ This all occurred despite earlier Japanese expressions of Asian brotherhood. In time the Japanese brutally dashed any hopes the conquerors may have had in gaining support of the local Singaporean population.

Apart from trying to coerce the population to unify as Asians, the Japanese set in place policies to sweep away any of the earlier colonial super structure. Instead Syonan was to become a self-sufficient state with regard to its industry, communications, commerce and finance all harnessed to the war effort. ${ }^{27}$ This was a significant change for the freetrading and outward-oriented entrepôt of earlier times. Large Japanese enterprises like Mitsui and Mitsubishi were given control of important branches of the Malayan economy. Import substitution was practiced, albeit in rudimentary form. Pineapple fiber, for instance, was substituted for rope and string; paper was made from bamboo; and grease and lubricants made from palm oil. By the middle of 1942 there was a large influx of Japanese businessmen to Singapore and the first Singaporean built steam ship was launched in November of the same year. 
Conversion to Japanese military script, by way of currency, hastened rampant inflation. Singapore was further enfeebled economically through a pernicious policy of income extraction, mainly at the expense of the Chinese population, that was to be gifted to Japan to help them in their war effort. By and large Japanese possessions were seen to be self-financing with regards to services. Food also became in short supply, especially with regards to staples such as rice and also more generally due to the overall shift to self-sufficiency and away from free trade with the outside world, one of Singapore's lasting hall marks. No more benignly the Japanese set about to alter the Singaporean education system, stressing loyalty and national consciousness with strong accents on technical and vocational instruction. With regard to natural and real assets, the reservoirs were preserved, vegetable gardens were encouraged in-lieu of plantations and cash crops. ${ }^{28}$ The Japanese were also persuaded to preserve the botanic gardens and the famous Raffles Museum collection, with Kwan Koriba, a Japanese botanist in control.

The war-time industrialization campaign, however, proved to be superficial and ephemeral, although also demonstrating Singaporean ingenuity and capacity for further industrialization. ${ }^{29}$ Nevertheless, as one author put it: "Instead of Asian brotherhood the Japanese brought cruelty and tyranny". They also conveyed racial arrogance and a feeling of superiority that also undid many of their plans. Little came of Japanese schemes for physical redevelopment of Singapore other than clearing buildings and basically rehabilitating services from prior to the occupation. One conspicuous exception was the construction in 1943 of an airport at Changi using prisoners of war labor that was completed in 1945, becoming the forerunner or today's vast international airport. The year 1943 was also something of a turning point in Japans fortunes of war. At much the same time the nascent Indian independence movement, tacitly if not modestly supported by Japan, began to gain traction. By November of 1944 the Americans began air raids over Singapore Harbor though careful to not inflict damage on non-Japanese sites. In August of 1945 the Japanese surrendered to the Allied Forces and in September Singapore was liberated. Rule was handed back to the British, although continued British hegemony was in doubt. In the months immediately following the collapse of British power in Malaya, the Colonial Office began drawing up schemes for radical post-war reorganization. One of its first proposals grouped the Malay States; Straits States; North Borneo; Sarawak and Brunei into a single union, with Singapore as its natural centre of trade and communication. This was abandoned as too complicated and out of the feeling that London did not want to jeopardies Malayan Union, important to them against communist insurgents, by trying to include Singapore. Instead it saw Singapore as a vital free port, defensive base, and a way of assuaging Malay strong fears of Singaporean domination should they be included in the Union. 


\section{POST-COLONIAL DEVELOPMENTS}

Under its avowed commitment to decolonize, while ensuring a non-communist take-over of its possessions, Britain pursued a policy of tactical convenience and separation of Singapore from other states in the Malay Federation. The United Malay National Organization, or UMNO, was founded in 1946 under Tunku Abdul Rahman and took a strong position against the union of Singapore in what became Malaysia. ${ }^{30}$ The origins for this were ethnic, cultural and also, as mentioned earlier, the fear of Singaporean domination. On the Singaporean side, in 1949 Lee Kuan Yew and some of his fellow students from Cambridge set up the Malay Forum and decided to push for an independent, socialist Malaya, but included Singapore which they saw as being too small to survive on its own. Later on in 1954 Lee formed the People's Action Party (PAP) together with allies from the Malay Communist Party, taking an anticolonial line which the communist supported more strongly. Then in 1959 during the general election for an autonomously governed Singapore, Lee and the PAP won with Socialist although not Communist support. In 1963, then-Prime Minister Lee Kuan Yew signed the Malaysia Agreement in London. This resulted in the formation of the Federation of Malaysia consisting of Singapore, Malaya, Sarawak and North Borneo (Sabah). However, in August of 1965 via the Singapore Amendment to the Malay Federation, Singapore was summarily ejected. Suddenly Lee and the PAP were faced with a nation building process despite their wishes and prior commitments. Quoting Lee Kuan Yew at the time, "We must survive... Just as a river loops and bends before it reaches the sea, so the history of a people takes many loops and bends before it reaches its destiny... Everybody will have their place, equal language, culture and religion... we could not achieve multiracialism and integration in Malaysia. But we will achieve it in Singapore". 31

When the leadership looked around Singapore what did they find? In short, they found a fragmented society with substantial socio-economic and dependency problems. First there was rising unemployment, as much as 17 percent to 20 percent and declining free trade. ${ }^{32}$ Second there was exploding population growth with refugees from Malaya shifting from re-federation, among others. The actual rise was from about 1 million people in 1950 to over 2 million by 1970. Third, there were appalling living conditions for many with spot densities of 2000 people per hectare and less than 10 square meters of livable space standard per person. Much of this was due to massive overcrowding. There were also some 300,000 people in squatter settlements in addition to around 250,000 people living in slums. Segregation of population also led to race riots in the 1960s. Then there was substantially deteriorated infrastructure due to neglect in the wartime years and finally there were shaky situations with neighboring countries, like the conflicts in Indonesia of 1965 and the water dependency on Malaysia through the water agreements of 1961 and 1962. In these last regards, Singaporeans also remembered well a time during the Japanese invasion when water was severely constrained due to damaged supply pipes, placing them in dire strait. The 1961 agreement signed by the Singapore City Council with the State of Johor in Malaysia, lasted until 2011, whereas the 1962 agreement extended the supply up to 250,000,000 gallons a day from Johor until $2061^{33}$. 

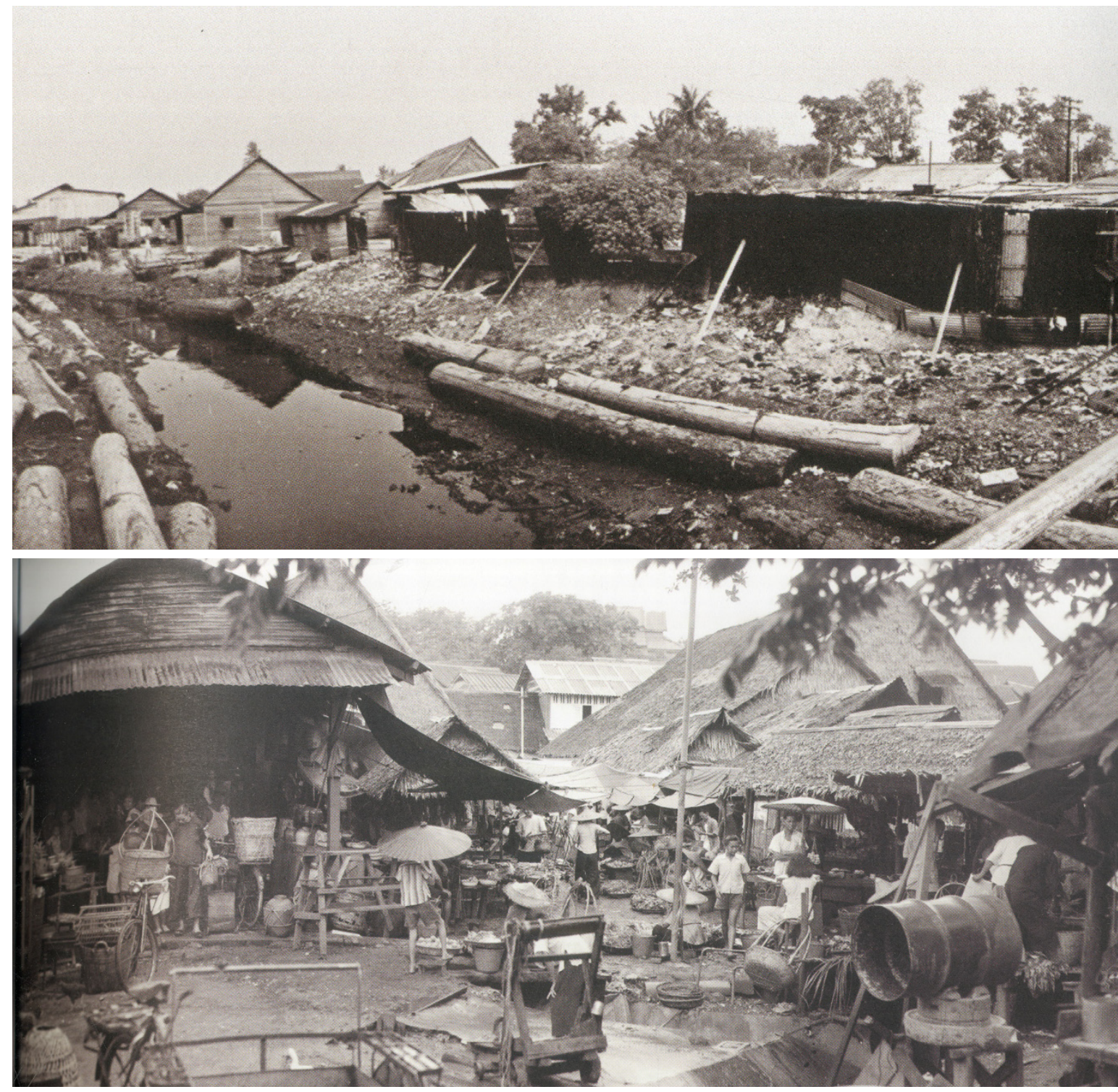

19.SQUATTER SETTLEMENTS IN SINGAPORE

Economic prosperity was to be secured by capitalizing on local assets. These included a relatively low cost, well-educated local labor force, dating back into the colonial period. Also, Singapore was to make itself open to trade as in the past and to encourage investment. It was also to move from a dependence on entrepôt trade in this regard to modern industrialization. Moving forward, Singapore engaged in an effective form of 'collective consumption' led by the government making Singapore an attractive place for foreign investment and manufacture. ${ }^{34}$ Here there was to be an insistence on political stability and a clean bureaucracy. The English-speaking legacy of the past was also to be continued lowering potential friction with potential outsiders from the United States, for instance, and from Europe. Then there were plans to create sophisticated infrastructure and 


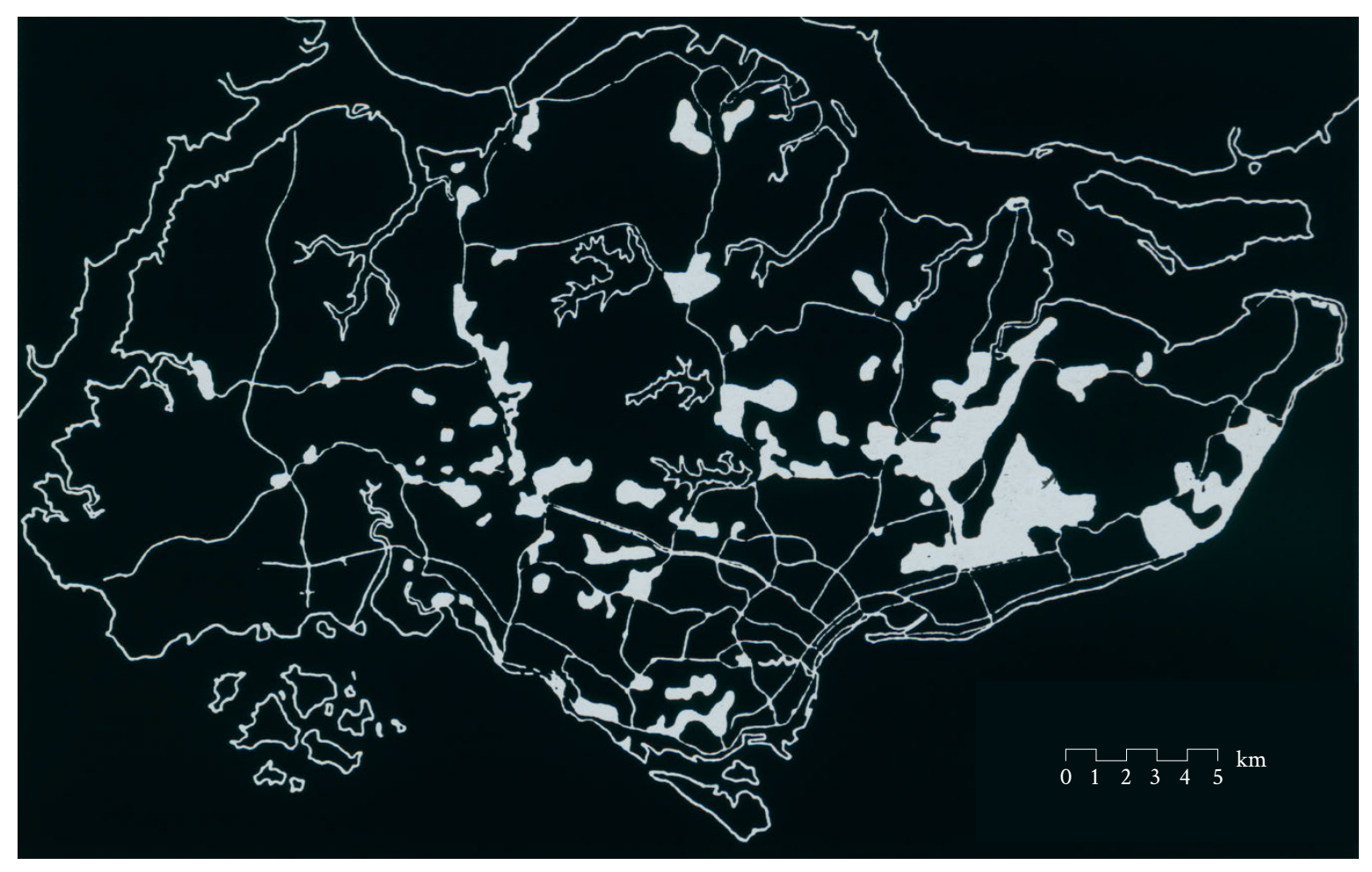

20.MAP OF SINGAPORE'S SQUATTER SETTLEMENTS

other basic improvements that would foster economic growth, capital accumulation and attract foreign investment. This involved three basic components. First, there was to be provision of public housing to help reduce and stabilize living costs and thereby enable the provision of cheaper labor. Then there were plans to build industrial infrastructure to offset the need for extensive foreign investment and, finally, to provide ready facility and turn-key projects for foreign enterprises such as those in the Jurong Industrial Park. Throughout, use was to be made of institutional boards and other British legacies. The Housing and Development Board (HDB) was established in 1960 as one of the super boards and then the Economic Development Board was begun in 1962. The Jurong Town Corporation, for example, was paired with the Economic Development Board and the Urban Redevelopment Authority (URA) was placed in relationship to the Housing and Development Board as an authority with both regulatory and developmental power, similar to Boston's Redevelopment Authority in the United States.

To both guide and orchestrate urban development activities and to promote orderly urban growth. Master-planning exercises were conducted across the island in several steps. First, British ideas on future development of Singapore conceived in the waning years of colonial rule were contained in the 1958 Masterplan. Then, E E. Lorange, a Norwegian planner, was hired with United Nation's assistance to produce a revised plan, followed in 1963 by a further United Nation's sponsored team of Koenigsberger, Abrams and Kobe that led to a so-called 'Ring City Plan', incorporating a more or less circular transportation armature around the central catchment area of the island and from which urban development could be organized $^{35}$. This effort was extended in 1965 into a competition for consultation which was 


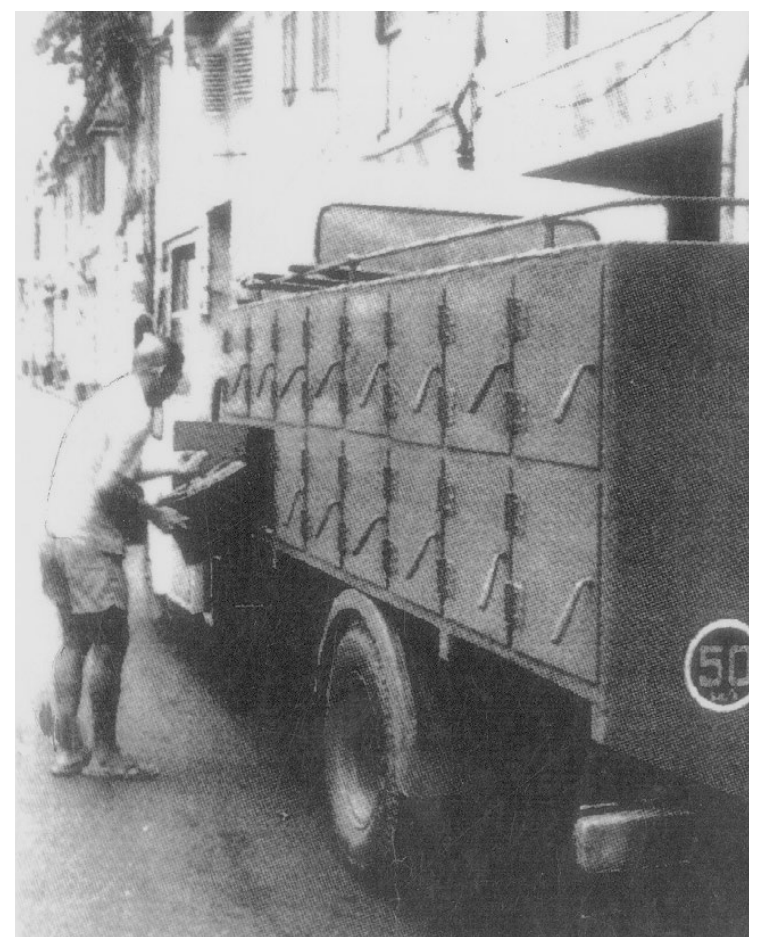

\section{A NIGHT CART IN OPERATION}

won by the Australian firm of Crooks, Michael, Peacock, Stewart Pty, Ltd. and led by Henry Wardlaw an Australian from Sydney. This exercise resulted in the 1971 Concept Plan, which incorporated the earlier 'Ring City Plan' idea and elaborated on it to produce a plan for Singapore capable of accommodating a population of four million inhabitants by $1992 .^{36}$ In addition to the transportation ring around the central catchment area, by way of two north-south corridors, sites for new communities and housing estates were located along these corridors, including both expressways and lines of mass rail transit. Heavy industries were planned at the western end of the island in Jurong, and Singapore's international airport was planned at the eastern end of the island in Changi, also with some industry. Both locations avoided conflict with existing and planned urban areas and both were also to be integrated with the island-wide mass transit system. Overall, the plan provided for a heavy belt of urban development along the south coast, with intermediate intensities around dispersed centres.
A master-planning process was established whereby 'concept plans' would be reviewed every ten years, but with mandatory quinquennial reviews of master plans set within the successive 'concept plans. ${ }^{37}$ In effect, this has yielded 'concept plans' in 1971, 1991, 2001, and 2011, with meso-scale master plans in 1965, 1970, 1975, and 1985. Before 1998, the Master Plan served as a "blueprint" document that was only updated periodically to capture developments that already existed, or had already been approved. The Master Plan did not actively communicate future planning intentions and permissible uses, and planners were instead guided by confidential "drawer" plans when assessing development applications. The "Development Guide Plans" prepared in the 1990s laid out future planning intentions for each planning area in a transparent and systematic manner. The plans were completed by 1998 . This process contributed to the development of the new Master Plan, which was gazetted, detailing future plans and permissible future developments on each parcel. Once the planners had a good base of Master Plan, there was no longer a need to develop similar 'Development Guide Plans', though the process of it are incorporated into each Master Plan review.

With regard to water resources, after 1965, Singapore intensified its efforts to diversify the sources of water supply rather than depending mainly on the water from Johor. In 1971 a Water Planning Unit was created within the Prime Minister's Office to study the scope and feasibility of new conventional sources of supply, as well as unconventional sources involving water re-use and desalination. This study resulted in the first Water Master Plan of 1992, outlining strategies for local resources involving more local catchment, NEWater recycled water and desalinated water. Initially, the Water Planning Unit sought the expertise of Tahal Consultants from Israel. However, the water resource conditions in Israel were very different from those in Singapore and so the Water Planning Unit struck out more independently on its own master plan with a 20 -year horizon until $1998 .{ }^{38}$ They also acknowledged that, over time, any specific single water conserving 


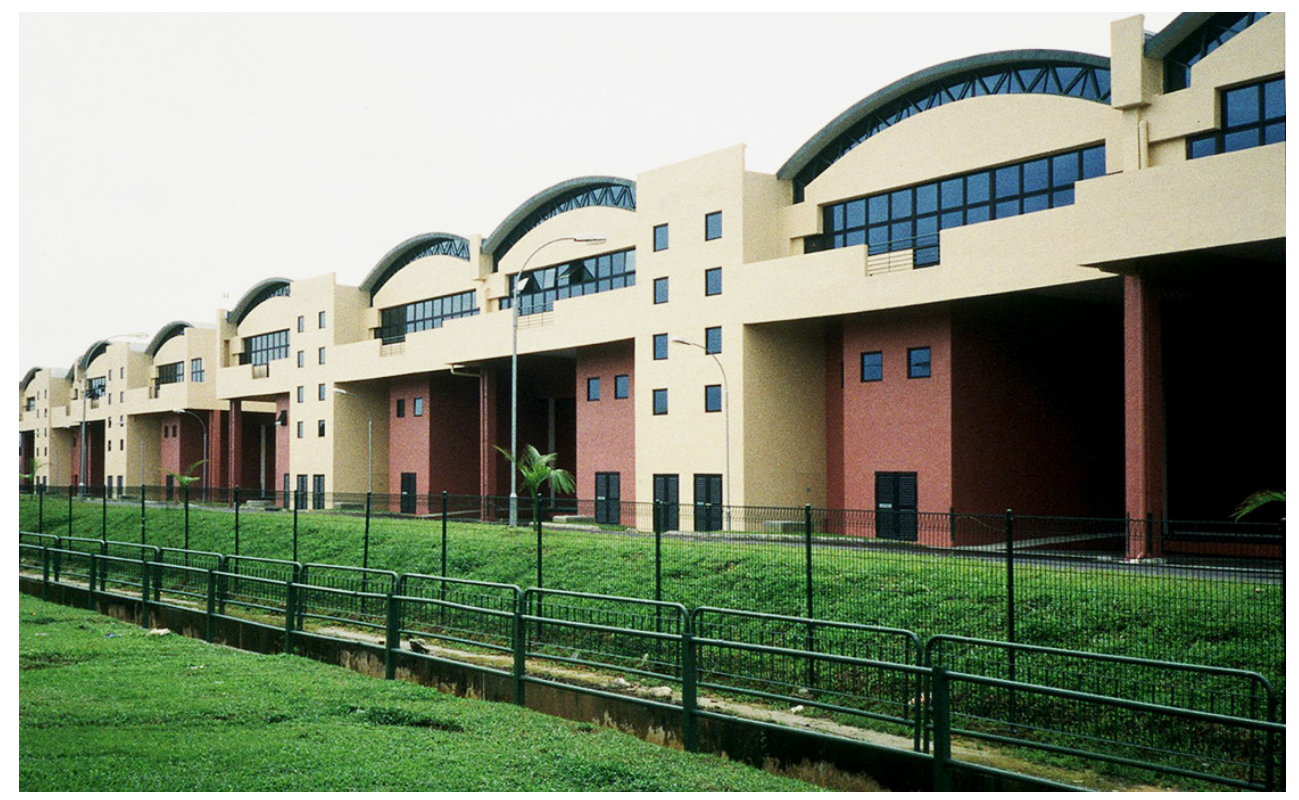

22. A TURNKEY FACTORY IN THE JURONG INDUSTRIAL PARK

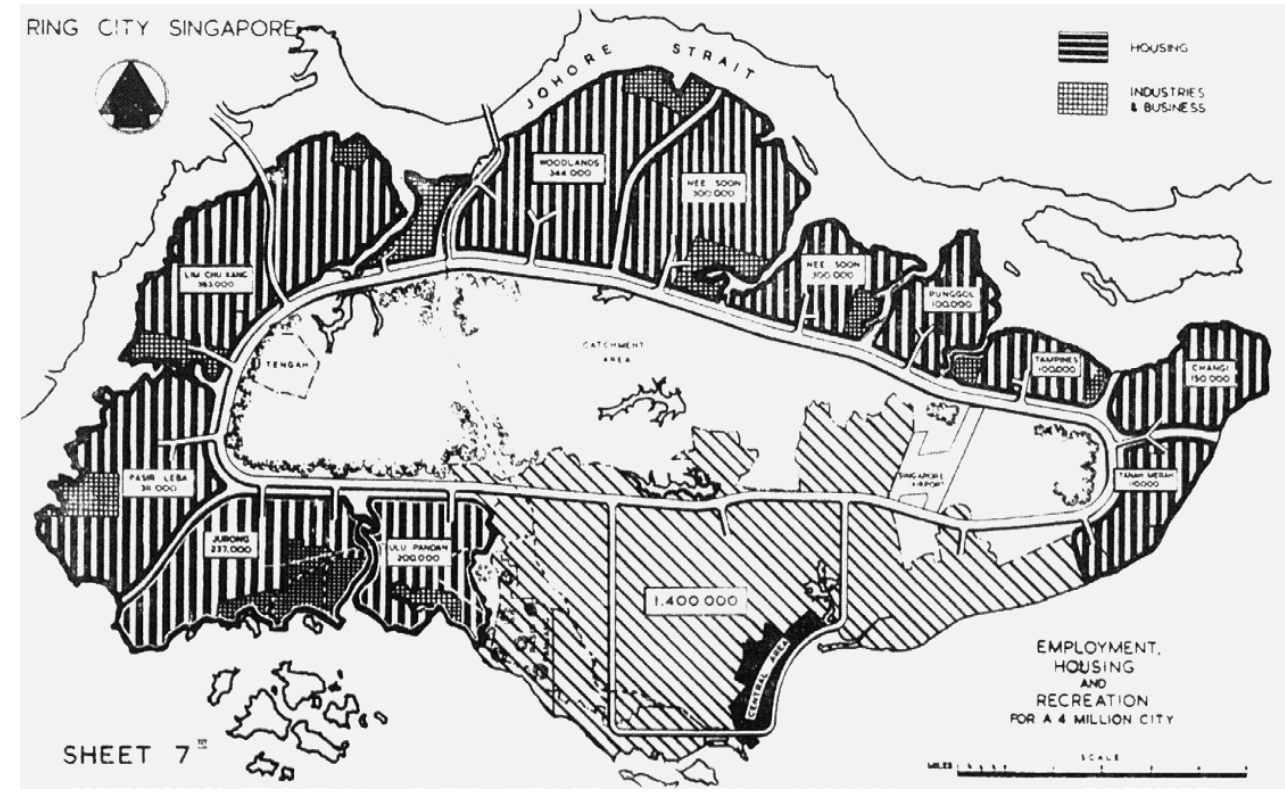

23. THE KOEINGSBERGER RING CONCEPT PLAN OF 1963, WHICH WAS EVENTUALLY INCOPORATED INTO THE LATER 1971 CONCEPT PLAN 
industry could upset demand forecasts both widely and quickly. The supply system options in their 1972 plan included other surface water sources including reservoirs at Bedok, Kranji-Pandan Dam and within the western and eastern catchments. They also recognized the need for water supply co-existing with other adjacent land uses, meaning urban stream water generally, as well as estuary barrage sources of supply and damming of rivers. Ground water proved to have poor potential at the time and so serious consideration began to be focused on recycled or reused water. In this regard treated effluent as a source of potable water supply was not advocated. But particulate objects might be removed, if the treated effluent was first diluted in a large impounding reservoir affording long retention periods and undergoing self-purifying processes prior to withdrawal for treatment needs. Desalination, by contrast, was considered a reliable source not subject to weather fluctuations, although costly still to bring on-line fully. In 1966 the Jurong Industrial Waterworks was completed, introducing an inexpensive source of low-quality water not requiring potable water quality standards. Also, in 1974 an advanced pilot water reclamation plant was established by the Ministry of Environment and thenPublic Utilities Board, with secondary treated effluent undergoing reverse osmosis and other advanced treatment processes of iron exchange, electro-dialysis and ammonia stripping to produce water complying with drinking water standards. However, the membrane in this membrane technology proved to be expensive and not very reliable. The plant closed after fourteen weeks. Nevertheless, the die, so to speak, was cast for NEWater to come on-line. Then on the Malaysian front, the 1962 water agreement was supplemented by the 1990 water agreement, scheduled to expire in $2061 .^{39}$

In 1963, Prime Minister Lee Kuan Yew put forward the idea of Singapore being a 'clean' and 'green' 'garden city', despite high-density development, limited land space and other resource constraints. ${ }^{40}$ He also started the 'tree planting program' that was to have fairly immediate effect on Singapore's urban landscape. One compelling reason for the clean and green' program was the need to collect as much of the 241.3 centimeters per year in rainfall as was possible. In this regard the 1963 drought was something of a wake-up call for further action. Another compelling reason was to make Singapore an attractive city, especially for direct foreign investment and to give Singaporeans a pride in their environment along with a sense of national solidarity. Around this time and in accordance with the Cleary Report of 1970, Singapore adopted an integrated approach to land development, mitigating environmental impacts, building only on designated sites. In effect, water security had challenged government to become crucially concerned with their environment. An Anti-Pollution Unit was also placed under the Prime Minister's Office, helping Lee Kuan Yew to realize his plans for Singapore to quickly become a clean, green and first-world city-state. ${ }^{41}$ 


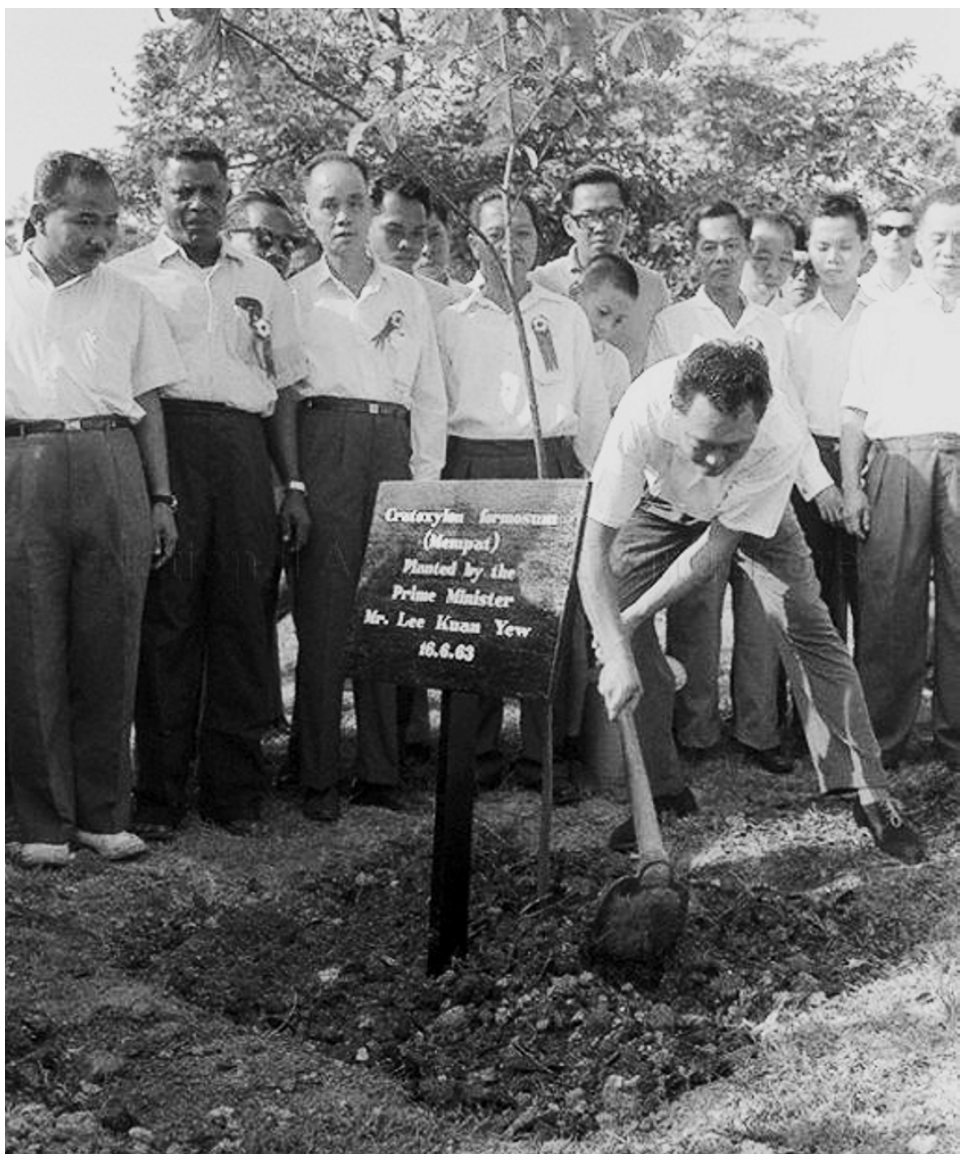

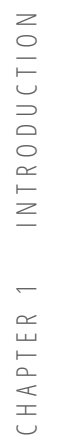

24.PRIME MINISTER LEE KUAN YEW

PLANTING A TREE 


\section{nd notes}

1. Turnbull, C.M. 1977. A History of Singapore, 1819-1975.First Edition, (Singapore: National University of Singapore), p.2.

2. Turnbull, p.1.

3. Sathiamurthy, E. and H. K. Voris.2006. "Maps of Holocene Sea Level Transgression and Submerged Lakes on the Sunda Shelf" The Natural History Journal of Chulalongkorn University, p.1f.

4. Turnbull, p.3.

5. Paragraph based on Turnbull, p.3-4.

6. Chew, Ernest C. T. and Edwin Lee. Eds. A History of Singapore (New York: Oxford University Press), pp..116-117.

7. Turnbull, p.4.

8. Paragraph based in part on Turnbull, pp.4-5.

9. Paragraph based in part on Perry, Martin; Lily Kong and Brenda Yeoh. 1997. Singapore: A Developmental City-State (New York: John Wiley and Sons), p.23 and p27.

10. Turnbull, p.11

11. See location and dimension on the accompanying plan.

12. O’Dempsey, Tony. 2014. “Singapore's Changing Landscape Since c. 1800”, in Timothy P. Barnard ed. Nature Contained: Environmental Histories of Singapore (Singapore: NUS Press), p.18.

13. Barnard, Timothy P. 2014. "Introduction", in Timothy P. Barnard, ed. Nature Contained: Environmental Histories of Singapore (Singapore: NUS Press), P.3.

14. Paragraph based in part on O’Dempsey,p. 21 and p.22.

15. Paragraph based in part on O'Dempsey, p.23 and 0.28

16. Paragraph based in part on O'Dempsey, p.28, p.32 and p.32f

17. Paragraph based on Turnbull, p.73, p.95 and p.97.

18. See graph of population statistics in Chapter 1 .

19. Turnbull, p138f.
20. Turnbull, p140f

21. Paragraph based in part on O'Dempsey, p.38, p.39 and p40.

22. Paragraph based in part on O'Dempsey, p. 35 and p.42f.

23. Paragraph based in part on O'Dempsey, p.29 and p.47.

24. Paragraph based in part on O'Dempsey, pp.20-30

25. Perry, p.46

26. Turnbull, p.190f.

27. Paragraph based in part on Turnbull, p198, p.200, p201 and p.202.

28. Taylor, Nigel P. 2014. "The Environmental Relevance of Singapore”, in Timothy P. Barnard, ed. Nature Contained: Environmental Histories of Singapore (Singapore: NUS Press), p.129f.

29. Paragraph based in part on Turnbull, p.201, p.205, p.206 p.211, p.216, p.217 and p.218.

30. Partially based on Hack, K., Margolin, J.L., and Delaye, K. (2010). Singapore from Temasek to the 21st Century: reinventing the Global City (Singapore: NUS Press) Chapter 10, pp. 243-291

31. Transcript of a press conference given by the Prime Minister of Singapore, Mr. Lee Kuan Yew at Broadcasting House, Singapore at 1200 hours on Monday 9 August, 1965

32. Perry, p.48f

33. Tortajada, Celia; Yugal Joshi and Asit K. Biswas. 2013. The Singapore Water Story: Sustainable Development in an Urban City-State (New York: Routledge), p.14.

34. Castells, Manuel, Lee Goh and R.Y. Kwok. 1991. The Shek Kip Mei Syndrome: Economic Development and Public Housing in Hong Kong and Singapore (Los Angeles: Sage Publications, Ltd.)

35. Perry, p. 192.

36. Interview with Dr .Liu Thai Ker on 10 August, 2017. 
37. Perry, p. $192 \mathrm{f}$.

38. Tortajada et al., 2013. p15-16.

39. Paragraph based in part on Tortajada, p.15, p.16, p.17 and pp.24-25.

40. Paragraph based in part on Tortajada, p35, p.39 and 46.

41. Paragraph based in part on Tortajada, pp.64-65.

\section{() (1)}

Open Access This chapter is licensed under the terms of the Creative Commons Attribution 4.0 International License (http:// creativecommons.org/licenses/by/4.0/), which permits use, sharing, adaptation, distribution and reproduction in any medium or format, as long as you give appropriate credit to the original author(s) and the source, provide a link to the Creative Commons license and indicate if changes were made.

The images or other third party material in this chapter are included in the chapter's Creative Commons license, unless indicated otherwise in a credit line to the material. If material is not included in the chapter's Creative Commons license and your intended use is not permitted by statutory regulation or exceeds the permitted use, you will need to obtain permission directly from the copyright holder. 